\title{
Agglutination reactions of human leucocytes ${ }^{1}$
}

\author{
JEANETTE SCHULZ AND HELGA MULLER \\ From the Department of Pediatrics, School of Medicine, University of California, \\ Los Angeles
}

SYNOPSIS Agglutination tests with various sera and leucocytes from 58 leukaemic patients and 61 patients without leukaemia are reported.

The agglutination of white blood cells by guinea-pig serum is of limited value in the diagnosis of leukaemia, though the test may be helpful in distinguishing leukaemia from other lymphomatous disorders.

Leuco-autoagglutinins were demonstrated more frequently than expected. Eleven leukaemic and six non-leukaemic sera agglutinated autologous leucocytes.

White blood cell agglutinins showed no apparent relationship to maturity or numbers of circulating leucocytes or to previous blood transfusions, $x$-irradiation, or therapy with antimetabolites.

White blood cells have been tested for agglutination by various sera and serum fractions in an attempt to define reactions peculiar to the leukaemic cell. Of particular interest was the substance in adult guineapig serum which agglutinates human leukaemic white blood cells and A.K.R. mouse leukaemia cells (Schoolman, Schwartz, and Spurrier, 1955). In 423 tests Schwartz, Schoolman, and Spurrier (1955) found positive agglutination reactions in 52 of 56 leukaemic patients and 'false positives' in only three patients with advanced tuberculosis. Other investigators have reported negative reactions with guineapig serum (Landtman, Wegelius, and Tähkä, 1954; Saint-Paul, McNulty, and Moloney, 1951-52). Our results show differential agglutination of leukaemic cells by guinea-pig serum though with less specificity than would be desirable in a diagnostic test.

The present study included agglutination tests with sera from human leukaemic and non-leukaemic patients, normal type $\mathrm{AB}$ human serum, guinea-pig serum, bovine albumin, and guinea-pig gamma globulin. White blood cells of normal individuals, of patients with leukaemia and other malignant diseases, and of patients with diverse non-neoplastic disorders were tested.

\section{REAGENTS}

SERUM Serum was separated by centrifuging sterile clotted venous blood and was frozen until use. Lyophilized

'Supported (in part) by the cancer research fund of the University of California.

Received for publication 6 February 1963. adult guinea-pig serum from Cappel Laboratories was reconstituted with distilled water and used for some experiments.

Bovine Albumin A $2 \cdot 2 \mathrm{~g} . \%$ solution of the Hyland Laboratories preparation was used.

GUINEA-PIG GAMMA GLOBULINS These were prepared by Weimer's adaptations of the Nichol and Deutsch method of separation (Weimer, Boak, Carpenter, RedlighMoshin, Drusch, and Miller, 1955). A solution of approximately $1.0 \mathrm{~g} . \%$ in $0.85 \mathrm{NaCl}$ was used for the tests.

WHITE BLOOD CELL SUSPENSIONS Venous blood was mixed with one-tenth of its volume of an isotonic potassiumammonium-oxalate mixture (Wintrobe) and allowed to settle in a tube inclined at an angle of $45^{\circ}$ for 15 to 45 minutes at room temperature. The speed of sedimentation $\frac{D}{O}$ is influenced by the haematocrit of the specimen. The supernatant plasma rich in white blood cells was removed $\mathrm{N}$ and centrifuged for five minutes at $500 \mathrm{~g}$. The clear layer of plasma was discarded and the sedimented leucocytes $N$ were washed twice and resuspended in $0.85 \%$ saline. The $N$ final suspension was adjusted to 5,000 to 10,000 W.B.C./ c. $\mathrm{mm}$.

\section{AGGLUTINATION TEST}

The procedure used was essentially the same as that reported by Schwartz et al. (1955).

Of the suspension of white blood cells, $0.05 \mathrm{ml}$. was $\cong$ added to $0.1 \mathrm{ml}$. of test serum in a tube, mixed thoroughly, and incubated in a water bath at $37^{\circ} \mathrm{C}$. for one hour. $\bar{\sigma}$ Control specimens of normal and test white blood cells in saline were incubated simultaneously. Agglutination $ᄋ$ 
was visible macroscopically but all tests were checked microscopically. Agglutination is rarely visible before 15 minutes of incubation and is well developed at one hour. Specimens not tested immediately after venepuncture were discarded since normal white blood cells may form clumps in several hours at room temperature. Positive agglutination reactions were not reversible by shaking the tubes, by washing the agglutinated cells in saline or Seligman's solution, or by refrigeration.

Agglutination was estimated as 1 to $4+$ on the basis of approximate size of the clumps of white blood cells which varied from five to innumerable cells. This assessment seemed inconsequential since it could not be quantitated. Though some white blood cell specimens consistently gave larger clumps than others, single white blood cells were rarely seen when agglutination occurred.

\section{RESULTS}

Agglutination tests with leucocytes from leukaemic patients and non-leukaemic patients with other diseases were done using the following sera or serum fractions: Normal human serum pooled from blood type AB donors, bovine albumin, the patient's own serum, adult guinea-pig serum, and guinea-pig gamma globulins. Normal leucocytes from blood type $\mathrm{O}, \mathrm{Rh}$-negative donors were used for controls and did not react with any of the reagents.

None of the leucocytes tested agglutinated with type AB human serum or with bovine albumin. Table I shows the positive results of 267 agglutination tests with leukaemic white blood cells and 71 tests with non-leukaemic white blood cells. In agglutination tests with leukaemic white blood cells 248 individual cell specimens $(93 \%)$ were positive with guinea-pig serum; $21(8 \%)$ were positive with the patient's own serum, i.e., autoagglutination occurred; and $11(4 \%)$ were positive with guinea-pig gamma globulins. Table I also shows the multiplicity of reactions of a given specimen of white blood cells. Some leucocytes were agglutinated by only one reagent used. Others were agglutinated by several.

In seven agglutination tests with non-leukaemic white blood cells (Table I), $14(20 \%)$ were positive with the patient's own serum (autoagglutination); $12(17 \%)$ were positive with guinea-pig serum; and four $(6 \%)$ were positive with guinea-pig gamma globulins. Multiple agglutination reactions with individual specimens of white blood cells occurred as noted in Table $\mathrm{I}$.

Twenty-nine (11\%) of the 267 agglutination tests with leukaemic white blood cells showed no agglutination with any of the reagents used. Fifty-three $(75 \%)$ of the 71 agglutination tests with non-leukaemic white blood cells were negative with all reagents.
TABLE I

\section{AGGLUTINATION REACTIONS OF WHITE BLOOD CELLS}

No. of

Positive

Tests Agglutination of White Blood Cells

Tests with leukaemic white blood cells

229 Agglutinated by guinea-pig serum but not by guinea-pig gamma globulins or patient's own serum

10 Agglutinated by guinea-pig serum and gamma globulins and by patient's own serum

9 Agglutinated by guinea-pig serum and patient's own serum but not by guinea-pig gamma globulins

2 Agglutinated by patient's own serum

1 Agglutinated only by guinea-pig gamma globulins

Agglutination tests with non-leukaemic white blood cells

8 Agglutinated by guinea-pig serum and patient's own serum but not by guinea-pig gamma globulins

5 Agglutinated only by patient's own serum

2 Agglutinated only by guinea-pig serum

1 Agglutinated by guinea-pig serum and gamma globulins but not by patient's own serum

1 Agglutinated by guinea-pig serum and gamma globulins and by patient's own serum

1 Agglutinated only by guinea-pig gamma globulins

Leukagglutination tests with a panel of human leukaemic sera and leukaemic white blood cells failed to uncover a human serum which would differentially agglutinate human leukaemic cells.

Twenty-one agglutination tests with 11 leukaemic patients' leucocytes and 14 tests with leucocytes from non-leukaemic patients showed evidence of leuco-autoagglutinins, i.e., the patient's serum agglutinated his own leucocytes. Leuco-autoagglutinins are rare and have not been reported in patients without a blood dyscrasia. Killmann (1959) has suggested a possible association between leucocyte agglutinins and leucopenia in patients who had not been transfused. Six of the 17 patients with autoagglutinins had never been transfused and only one of these had a relatively low peripheral white blood count, 5,800 W.B.C.s/c.mm. However, four transfused patients with leuco-autoagglutinins had severe leucopenia; three of these had acute lymphatic leukaemia and one had myelofibrosis. Leucoautoagglutinins appeared most often in six patients with chronic lymphatic leukaemia and high peripheral lymphocyte counts. Of these, one also had active tuberculosis and one had severe thrombocytopenic purpura. Brody (1962), in a study of nine patients with chronic lymphatic leukaemia and Coombs-positive acquired haemolytic anaemia, reported immune adherence (autoagglutination?) with autologous leukaemic lymphocytes and the patients' sera and with their Coombs-positive red cell eluates. Only three of our six patients with chronic lymphatic leukaemia and leuco-autoagglutinins were tested by the Coombs technique and the tests were negative. The white blood cell agglutination tests with autologous sera remained positive in 
TABLE II

AGGLUTINATION OF LEUKAEMIC WHITE BLOOD CELLS WITH GUINEA-PIG SERUM

\begin{tabular}{|c|c|c|c|c|c|c|c|c|c|}
\hline \multirow[t]{2}{*}{ Leukaemic White Blood Cells } & \multirow{2}{*}{$\begin{array}{l}\text { Number of } \\
\text { Patients }\end{array}$} & \multirow{2}{*}{$\begin{array}{l}\text { Number of } \\
\text { Tests }\end{array}$} & \multicolumn{2}{|c|}{ Positive Tests } & \multicolumn{3}{|c|}{ Positive and Negative Tests } & \multicolumn{2}{|c|}{ Negative Tests } \\
\hline & & & Patients & Tests & Patients & $\begin{array}{l}\text { Positive } \\
\text { Tests }\end{array}$ & $\begin{array}{l}\text { Negative } \\
\text { Tests }\end{array}$ & Patients & Tests \\
\hline
\end{tabular}

Acute lymphatic

Acute myelocytic

Acute monocytic

Acute undifferentiated

Chronic lymphatic

Chronic myelocytic

Total

$\begin{array}{rr}12 & 45 \\ 15 & 80 \\ 7 & 36 \\ 2 & 4 \\ 16 & 80 \\ 6 & 22 \\ 58 & 267\end{array}$

45
80
36
4
80
22
267

10
12
4
0
11
4
41

41
74
28
74
12
229

three patients who responded to prednisone, chlorambucil, and cytoxan. The six non-leukaemic patients whose leucocytes were agglutinated by autologous sera had a variety of haematological diseases: the myeloproliferative syndrome, myelofibrosis, lymphocytosis of unknown cause, reticuloendotheliosis, and acquired haemolytic anaemia. The patient with haemolytic anaemia had a positive direct Coombs test. Her white blood cells were agglutinated by guinea-pig serum and guinea-pig 'gamma globulin' as well as by her own serum. Agglutination tests with the patient's red cells and guinea-pig serum were negative.

Results of tests with white blood cells from leukaemic patients and guinea-pig serum are summarized in Table II. Agglutination of leukaemic cells with guinea-pig serum was positive with freshly frozen and lyophilized guinea-pig serum, and guinea-pig serum heated to $56^{\circ} \mathrm{C}$. for 30 minutes. Seven patients had positive tests on some days and negative tests at other times. Positive tests were unrelated to therapy. Approximately $16 \%$ of leukaemic patients had persistently negative reactions. False negative agglutination tests with guinea-pig serum occurred before, during, and after therapy for leukaemia. Agglutination of white blood cells did not appear to be related to the type of leukaemia, the length of survival after diagnosis, the white blood cell count at the time of the test, or the presence of immature cells in the peripheral blood. Schwartz et al. (1955) reported that cortisone in vitro interfered with the agglutination reaction with guinea-pig serum. Positive agglutination tests with white blood cells from patients receiving prednisone ( 20 to $75 \mathrm{mg}$./day) were encountered more often than were false negatives during steroid administration. One test done on the third day of intravenous hydrocortisone administration (200 mg./day) was positive. Two leukaemic patients with consistently negative tests had been treated for many years for illnesses antedating the leukaemic state. One with acute myelocytic leukaemia was receiving colchicine $(2 \mathrm{mg}$./day) for gout; the

other with chronic lymphatic leukaemia was taking prednisone ( $2.5 \mathrm{mg}$./day) for rheumatoid arthritis.

Titration tests with guinea-pig serum and leukaemia cells were usually done to a $1: 256$ dilution though higher titres were occasionally demonstrated. Figure 은 1 shows the percentage of positive tests at various serum dilutions. Titres were generally higher with $\subsetneq$ white blood cells of myelocytic leukaemias than with lymphatic leukaemia cells. In the lymphatic group, $\vec{\mathscr{}}$ high titres were rare in acute leukaemia but more $\stackrel{\circ}{\circ}$ common in the chronic form of the disease.

Table III shows the results of agglutination tests with guinea-pig serum and non-leukaemic white blood cells of patients with a variety of selected diseases. About $10 \%$ of these patients had false $\stackrel{\varnothing}{\varnothing}$

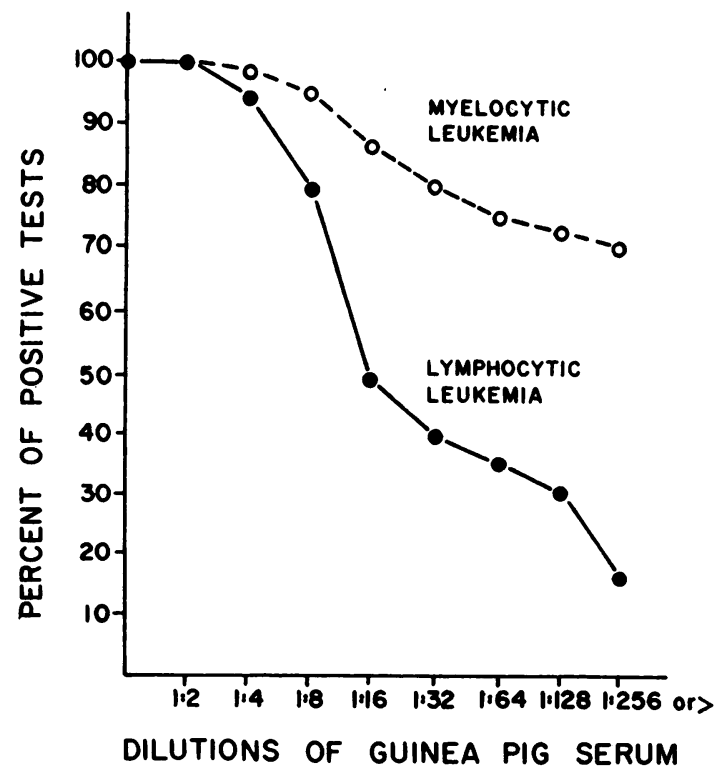

FIG. 1. Percentage of white blood cell agglutination tests $\stackrel{\mathbb{D}}{2}$ remaining positive with increasing dilutions of guinea-pig serum. 
TABLE III

GUINEA-PIG SERUM AGGLUTINATION OF NON-LEUKAEMIC WHITE BLOOD CELLS

\begin{tabular}{|c|c|c|c|c|}
\hline \multirow[t]{2}{*}{ Diagnosis } & \multirow{2}{*}{$\begin{array}{l}\text { Number of } \\
\text { Patients }\end{array}$} & \multirow{2}{*}{$\begin{array}{l}\text { Number of } \\
\text { Tests }\end{array}$} & \multicolumn{2}{|c|}{ Positive Tests } \\
\hline & & & Patients & Tests \\
\hline Hodgkin's disease & 12 & 16 & $2(17 \%)$ & $6(38 \%)$ \\
\hline Lymphosarcoma & 6 & 6 & 0 & 0 \\
\hline Lymphoma & 5 & 5 & $\mathbf{0}$ & $\mathbf{0}$ \\
\hline Wilm's tumour & 1 & 1 & $\mathbf{0}$ & $\mathbf{0}$ \\
\hline Neuroblastoma & 2 & 2 & 1 & 1 \\
\hline Reticulum cell sarcoma & 2 & 2 & 0 & 0 \\
\hline Carcinoma of breast & 1 & 1 & 0 & $\mathbf{0}$ \\
\hline Total & 29 & 33 & $3(10 \%)$ & $7(21 \%)$ \\
\hline Multiple myeloma & 5 & 7 & 0 & $\mathbf{0}$ \\
\hline Reticuloendotheliosis & 1 & 2 & 0 & $\mathbf{0}$ \\
\hline Myelosclerosis & 2 & 2 & $\mathbf{0}$ & $\mathbf{0}$ \\
\hline Polycythaemia rubra vera & $\overline{7}$ & 7 & 1 & 1 \\
\hline \multirow{2}{*}{\multicolumn{5}{|c|}{ Idiopathic thrombocytopenic }} \\
\hline & & & & \\
\hline \multicolumn{5}{|l|}{ Acquired haemolytic } \\
\hline anaemia & 2 & 3 & 1 & 2 \\
\hline S. lupus erythematosus & 2 & 2 & 0 & $\mathbf{0}$ \\
\hline Infectious mononucleosis & 4 & 4 & 0 & $\mathbf{0}$ \\
\hline Sickle cell anaemia & 2 & 2 & 0 & $\mathbf{0}$ \\
\hline Pernicious anaemia & 1 & $\overline{1}$ & 0 & $\mathbf{0}$ \\
\hline Iron-deficiency anaemia & 1 & 1 & $\mathbf{0}$ & 0 \\
\hline Persistent lymphocytosis & $i$ & 2 & $\mathbf{0}$ & $\mathbf{0}$ \\
\hline Tuberculosis & 1 & 1 & 0 & $\mathbf{0}$ \\
\hline Total & 32 & 38 & $3(9 \%)$ & $5(13 \%)$ \\
\hline
\end{tabular}

positive reactions. The two patients with Hodgkin's disease and positive tests apparently had localized disease which had responded well to $x$-irradiation. Vulpis and Pinto (1957) ventured the hypothesis that alterations of cellular structure from cytoxins, such as $x$ rays, may promote the emergence of autoantigenic leucocytes. The majority of $x$-irradiated patients in the present study had negative agglutination tests. The one child with neuroblastoma listed as a positive reactor had been treated with $x$ irradiation and had extensive bone marrow metastases when the guinea-pig serum test was done.

Several years' observation of other patients with false positive tests has failed to produce any evidence that leukaemia may be developing. One patient with polycythaemia rubra vera had a positive test and he has remained asymptomatic for the past three years. False positive tests before and after splenectomy were found in a boy with chronic idiopathic thrombocytopenic purpura. His Coombs tests and L. E. tests were negative and he has been clinically and haematologically normal since splenectomy two years ago. However, the positive guinea-pig serum reaction persists.

A prozone phenomenon was observed only in tests on four patients with infectious mononucleosis. Guinea-pig serum did not agglutinate white blood cells at titres less than $1: 16$ but agglutination became progressively more marked with increasing dilutions of serum.
Approximately 100 agglutination tests with guinea-pig serum and white blood cells from patients with non-neoplastic diseases other than those listed in Table III have been negative.

\section{DISCUSSION}

Though the majority of leukaemic leucocytes will agglutinate with guinea-pig serum and false reactions are rare, the agglutination test is not specific enough for a practical diagnostic tool. In most patients, the diagnosis of leukaemia, particularly the acute variety, is not difficult. However, the differentiation of lymphatic leukaemia and lymphosarcoma can be a diagnostic problem. None of the 11 patients with lymphoma and lymphosarcoma in this series had a positive agglutination test with guinea-pig serum. The significance of these results is lessened by the repeatedly false negative reactions encountered in some leukaemic patients.

There is still some doubt that the positive reaction with leukaemic cells is due to a specific agglutinin in the guinea-pig serum. Attempts to remove the agglutinating factor by repeatedly exposing guineapig serum to fresh suspensions of known reactive leukaemic white blood cells were unsuccessful. Whatever the guinea-pig factor is, it appears to be heat-stable and relatively specific since agglutination is rare with non-leukaemic cells. The tests with isolated guinea-pig gamma globulins gave no indication that this serum fraction of itself is important to the agglutination reaction. The relationship of the guinea-pig serum agglutinating factor and the factor in guinea-pig serum which causes lysis of some mouse lymphomas (Kidd, 1953; Herbut and Kraemer, 1958) is not known.

Steinberg and Martin $(1944,1946)$ and Korngold, Van Leeuwen, and Miller (1961) suggested that immature white blood cells develop specific antibodies for each phase of the maturation cycle. The antigenic similarity of normal and leukaemic white blood cells and the dissimilarity of lymphosarcoma cells and normal or leukaemic lymphocytes had also been reported by Steinberg and Martin (1958) and by Killmann (1958). It seems probable that not all antigens of human normal and leukaemic leucocytes are similar. The guinea-pig serum factor is capable of distinguishing between normal, leukaemic, and lymphomatous lymphocytes but not between the several types of leukaemic cells nor the stage of maturation of the cells. White blood cell agglutination requires intact cells and it is very difficult to remove adhered protein without lysing the cells. Nelken (1961) has presented evidence that a positive direct antiglobulin consumption test may be the result of normal plasma globulin adhering to 
the leucocytes. Rundles, Coonrad, and Arends (1954) and Fahey and Boggs (1960) have reported abnormalities of serum proteins in leukaemia. If all leukaemic cells were sensitized with antibody or coated with an abnormal serum protein, the addition of a guinea-pig serum might produce apparent agglutination by a conglutin-like effect.

The relatively high incidence of leuco-autoagglutinins found in this study did not appear to be correlated with the peripheral blood count, previous blood transfusions, or the severity of clinical symptoms. It seems possible that autoagglutination of white blood cells may in some cases have been the result of erythrophagocytosis and the mixed clumping phenomenon. Erythrocytes were rare in the white blood cell suspensions but elimination of all red cells or red cell ghosts was not achieved. Bakemeier and Swisher (1957) have shown that mixed clumping of all cellular elements of the blood could occur in the presence of a 'potentially' complement-fixing red cell antibody even if the sensitized red cells had been haemolyzed. The most generalized reactors encountered during this study were patients in whom mixed clumping and coated red cells would be most suspect, i.e., those with acquired haemolytic anaemia and chronic lymphatic leukaemia. It is possible that the higher agglutinin titres with guinea-pig serum in chronic lymphatic leukaemia as compared with acute leukaemia may be the result of a sensitivity reaction unrelated to specific leucocyte agglutinins.

\section{REFERENCES}

Bakemeier, R. F., and Swisher, S. N. (1957). Blood, 12, 913.

Brody, J. I. (1962). J. clin. Invest., 41, 471.

Fahey, J., and Boggs, D. R. (1960). Blood, 16, 1479.

Herbut, P. A., and Kraemer, W. H. (1958). Amer. J. Path., 34, 767.

Kidd, J. G. (1953). J. exp. Med., 98, 565.

Killmann, S. (1958). Vox Sang. (Basel), 3, 409.

(1959). Acta med. scand., 163, 207.

Korngold, L., Van Leeuwen, G., and Miller, D. G. (1961). J. nat. Cancer Inst., 26, 557.

Landtman, B., Wegelius, R., and Tähkä, H. (1954). Acta haemat. (Basel), 12, 188.

Nelken, D. (1961). Nature (Lond.), 191, 1110.

Rundles, R. W., Coonrad, E. V., and Arends, T. (1954). Amer. J.

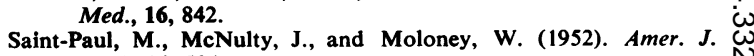
Med., 14, 524.

Schoolman, H. M., Schwartz, S. O., and Spurrier, W. (1955). Acta haemat. (Basel), 14, 1.

Schwartz, S. O., Schoolman, H. M., and Spurrier, W. (1955). J. Lab. clin. Med., 46, 709.

Steinberg, B., and Martin, R. A. (1944). Proc. Soc. exp. Biol. (N.Y.), 56, 50.

(1946). J. Immunol., 52, 71.

(1958). Acta haemat. (Basel), 19, 241.

Vulpis, N., and Pinto, L. (1957). Policlinico, Sez. med., 64, 171.

Weimer, H. E., Boak, R. A., Carpenter, C. M., Redlich-Moshin, J., Drusch, H. E., and Miller, J. N. (1955). J. infect. Dis., 96, 19. 